More praise for 1948: A History of the First Arab-Israeli War

"This is the best book by far on the war of I948."

-Benjamin Kedar, professor of history, The Hebrew University of Jerusalem

"This volume is a must read. . . A courageous narrative." -Michael Bell, Toronto Globe and Mail

"A crisp, vivid introduction to the historical tragedy of Palestine." -Max Hastings, Sunday Times (London)

"When it comes to interpreting the history they shared in 1947-49, Arabs and Israelis subscribe to two radically different narratives. . . One of the many achievements of this admirable book is to help readers understand why each narrative commands such authority and why they remain so stubbornly irreconcilable." -Andrew Bacevich, Boston Globe

"Morris offers a study of Israel's war of independence, effectively debunking many of the myths surrounding it. . . He meticulously documents the expulsions and atrocities that occurred on both sides. His work demonstrates that passion, not polemic, about this controversial era leads to good history. Recommended."

-Library Journal

"Morris' ... new book ... is notable for its insistence that the religious dimension of Arab opposition to Jewish sovereignty, the rejection of Israel as an 'infidel' and 'alien' presence, was overwhelming from the earliest days of the struggle for statehood - and was underestimated by Israel's leaders from the earliest days, too."

-David Horovitz, Jerusalem Post

"Magisterial. ... A densely researched, richly textured, nuanced book brimming with discerning analysis and telling details. . . It will be mandatory reading." -Sheldon Kirshner, Canadian Jewish News

“A compelling 'aha' book, 1948 brings order to complex, little-understood subjects ... with [Morris'] vivid narrative prose and masterly analysis."

—David Holahan, Hartford Courant 



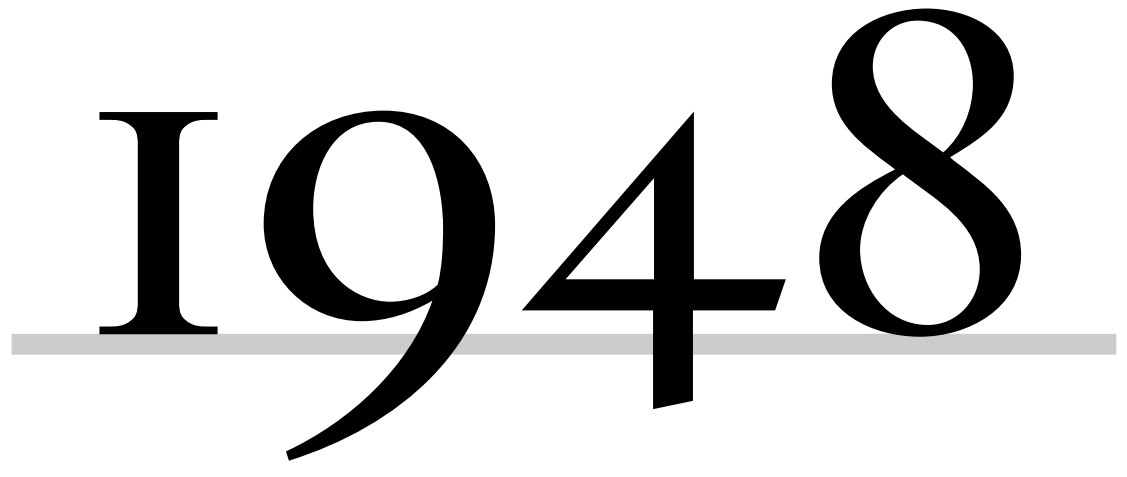

A History of the First Arab-Israeli War

\author{
Benny Morris
}


Copyright (c) 2008 by Benny Morris. All rights reserved. This book may not be reproduced, in whole or in part, including illustrations, in any form (beyond that copying permitted by Sections I07 and Io8 of the U.S. Copyright Law and except by reviewers for the public press), without written permission from the publishers.

"David," by Marie Syrkin, reproduced by kind permission of David Bodansky

Designed by Nancy Ovedovitz and set in Galliard Old Style by The Composing Room of Michigan. Printed in the United States of America.

The Library of Congress has cataloged the hardcover edition as follows:

Morris, Benny, 1948I948 : a history of the first Arab-Israeli war / Benny Morris.

p. $\quad \mathrm{cm}$.

Includes bibliographical references and index. ISBN 978-0-300-I2696-9 (clothbound : alk. paper)

I. Israel-Arab War, 1948-1949. 2. Palestine-History, Military-2oth century. 3. Palestine-Politics and government-I917-1948.

4. Palestine-History-I9I7-I948. 5. Haganah (Organization)History-2oth century. 6. Israel-History, Military-2oth century. 7. Israel-Politics and government-1948-1967. 8. IsraelHistory-1948-1967. 9. Israel-Foreign relations-Arab countries. Io. Arab countries-Foreign relations-Israel. I. Title.

$$
\begin{array}{cc}
\text { DSI26.9.M67 } & 2008 \\
956.04^{\prime} 2 \text { - dc22 } & 2007027380 \\
& \\
\text { ISBN 978-O-3OO-I5II2-I (pbk.) }
\end{array}
$$

A catalogue record for this book is available from the British Library.

$$
\text { IO } \quad 9 \begin{array}{lllllllll} 
& 8 & 7 & 6 & 5 & 4 & 3 & 2 & \text { I }
\end{array}
$$


For Eliya, Stav, Ayala, and Zohar

DAVID 


\section{Marie Syrkin}

Suppose, this time, Goliath should not fail; Suppose, this time, the sling should not avail On the Judean plain where once for all Mankind the pebble struck, suppose the tale Should have a different end: the shepherd yield, The triumph pass to iron arm and thigh, The wonder vanish from the blooming field, The mailed hulk stand, and the sweet singer lie.

Suppose, but then what grace will go unsung, What temple wall unbuilt, what garden bare; What ploughshare broken and what harp unstrung! Defeat will compass every heart aware How black the ramparts of a world wherein The psalm is stilled, and David does not win. 